\title{
INCOME APPROACH AND PROPERTY MARKET CYCLE
}

\author{
Maurizio D'AMATO ${ }^{\text {a,* }}$ \\ ${ }^{a}$ DICATECh, Politecnico di Bari, Via Calefati, 272-70122 Bari, Italy
}

Received 18 September 2013; accepted 31 March 2014

\begin{abstract}
This paper is focused on a proposed valuation method including real estate market cycle analysis in real estate valuation process. Starting from early works on this field (d'Amato 2003) the work highlight the dangerous gap between academic research on property market cycles and professional practice of property valuation. The danger of this gap comes from the fact that in spite it is well documented that the property market has a "natural" cyclical behaviour, the opinions of value based on income approaches still relies on assumption of a stable or perpetually growing (or decreasing) income. This may be one generating factors of the real estate bubble and the subsequent financial markets crisis experienced recently. This paper offers a general introduction on Cyclical Capitalization as a further family of valuation methodologies based on income approach. This method includes in the traditional Dividend Discount Model more than one g-factor in order to plot property market cycle. An empirical application of Cyclical Capitalization is offered to the office market of the Eastern London.
\end{abstract}

KEYWORDS: Real estate market cycle; Cyclical capitalization; Direct capitalization

\section{INTRODUCTION}

The non agency mortgage crisis created serious damages to global economies. It began when the real estate prices and price indices in the US and in the world ceased rising. The limits of the myth of an ever increasing real estate market price became dramatically evident. The role of understanding market cycle for valuation purposes has been increasingly stressed both in academic literature and in professional standards. Pritchett (1984) analysed the US real estate investment discovering that the best indicator of the cycle phase is the vacancy rate.

Hekman (1985) analyzed the office sector in fourteen cities over the 1979-1983 period demonstrating that the construction sector is cyclical. Cyclicality of vacancy rates among metropolitan areas has been highlighted in Voith and Crone (1988) by analyzing office market vacancy rates in seventeen large metropolitan areas in the U.S. Pyhrr et al. (1990) defined an interesting outlook of the role of market cycle in real estate market analysis. Roulac (1996) provides a qualitative study concluding that real estate markets are in-

\footnotetext{
* Corresponding author. E-mail: madamato@fastwebnet.it
}

fluenced by the economy, office demand, office construction, property values (d'Amato 2010), volume of transactions, capital for real estate, investor interest and tax climate factors Studying the determinants of Canadian commercial property prices, Clayton (1996) suggested that major market cycles may be detectable in advance potentially leading to arbitrage opportunities.

Pyhrr et al. (1999) addressed the importance of the market cycle for investment and portfolio management. Mueller and Laposa (1996) analysed rent distributions in different alternative market cycles. Other important contributions are Case and Shiller (1989), Borio et al. (1994), Case et al. (1997) demonstrating the cyclical nature of real estate prices. In a further study has been highlighted how typical market value appraisal of an incomeproducing property defines a set of current market conditions and economic trends that are assumed to remain stable into the future. For this reason many appraisals may overstate or understate value because they fail to consider the impacts of economic and market cycle variables (Pyhrr et al. 1996). Malpezzi and Watcher (2005) also examined whether land speculation is primarily a cause of, 
or a symptom of, property cycles. Property cycle research has the potential to assist low-income homeowners to better understand the characteristics of cycles and associated risks in each residential investment (Reed, Wu 2010). Recent analysis shows that traditional value techniques are successfully applied in stabilized and even accelerated growth periods, but weaken and even break down during down markets (DeLisle, Grissom 2011). Beyond the general overview on the literature related to property market cycle, this paper will be focused on the role of the cycle in the valuation of income producing properties.

The greatest part of the contributions focused the attention on the role of the market cycle at micro and macro level. Few contributions are focused on the integration between the property market cycle and the property valuation methods.

However, although the identification of property cycles drivers is an interesting matter, an income approach model taking into account property market cycle is proposed and applied in the present paper.

These methods originally defined cyclical dividend discount models (d'Amato 2003) are ridefined in this work as cyclical capitalization models (d'Amato 2014). The importance of real estate market phases in the valuation process has been also stressed by professional standards. Guidance Note n. 12 of the Appraisal Institute "Since the value of a property is equal to the present value of all of the future benefits it brings to its owner, market value is dependent on the expectations of what will happen in the market in the future. Therefore, a critical step in the development of a market value opinion is analysis of the market trends." (Appraisal Institute, Guide Note n. 12). The USPAP (United States Professional Appraisal Practice) in the Standards Rule 1-3 states "...in developing a market value opinion, an appraiser must: (a) identify and analyze the effect on use and value of existing land use regulations, reasonably probable modifications of such land use regulations, economic supply and demand, the physical adaptability of the real estate, and market area trends." (Appraisal Institute 2012). As a consequence there is an increasing attention in the role of the cycle in valuation activity. The International Valuation Standard 2011 address the problem in the IVS Framework in the paragraph 66 related to valuation inputs (IVSC 2011). The role of the cycle is relevant also in valuation for mortgage lending purposes. In the IVS 2011 and in particular the IVS 310 (Valuations of Real Property Interests for Secured Lending), in paragraph 3 is addressed that "The basis of value to be specified in accordance with IVS 101 para 2(e) will normally be market value" (IVSC 2011). The coincidence between the mortgage lending value and the market value is recurring in important real estate markets as USA. In mortgage lending value determination European Valuation Standards stressed the role of a long term value in the European Valuation Application n. 2 on Valuation for Lending Purposes. In this case the definition requires an analysis of future market trends. The paragraph on Mortgage Lending Value states "The choice of capitalization rates is also to be based on long term market trends and exclude all short term expectations regarding the return on investment. It should consider the sustainable income-producing capacity of the property, multy-purpose or appropriate alternative uses as well as the future marketability of the property" (EVA 2012).

The problem that may be raised is how to include property market cycle analysis in the opinion of value referring both to market value and to mortgage lending value. The model presented in this article tries to merge property valuation with property market cycle analysis in order to provide an opinion of value closer to real estate market dynamics. In particular in this paper will be presented the application of a model belonging to the primum group of these methodologies ${ }^{1}$. The work is organized as follows in the first paragraph are exposed the mathematical foundations of two models of cyclical capitalization. In the second paragraph a comparison between cyclical capitalization and the direct capitalization models is provided. In the third paragraph a brief application of the model to the office market of Eastern London is proposed. Final remarks will be offered at the end.

\section{CYCLICAL CAPITALIZATION}

Income approach is a real estate valuation methodology to appraise properties based on the "income that an asset will generate over its useful life and indicates value through a capitalization process. Capitalization involves the conversion of income into a capital sum through the application of an appropriate discount rate" (IVSC 2011, Framework para. 60). This approach is composed by three different groups of methodologies: income capitaliza-

\footnotetext{
1 d'Amato, M. 2014. Cyclical capitalization, in Lorenz, D.; Lutzkendorf, T. (Eds.). Beyond the price: valuation in a changing environment. Wiley Publishers, forthcoming. The model exposed in this work belongs to the so called primum group of Cyclical Capitalization models.
} 
tion, discounted cash flow and various option pricing models (IVSC 2011, Framework para. 61).

An appraiser referring to an infinite number of Net Operate Incomes will apply a direct capitalization. An appraiser valuing a finite number of income streams will refer to yield capitalization. Direct capitalization can be done applying a capitalization factor to the Net Operate Income or by using a constant growth model. The former method uses a constant Net Operate Income as indicated in the formula 1:

$$
V=\frac{N O I}{R_{0}} \text {. }
$$

In the formula 1 the NOI is the net operate income whilst the $R_{0}$ is the overall capitalization rate. Income capitalization based on explicit growth models is an application of the well known Dividend Discount Model (Gordon, Shapiro 1956; Gordon 1962) indicated in the formula 2:

$$
V=\frac{N O I}{Y-g}=\frac{N O I}{Y-\Delta a} \text {. }
$$

In the formula 2, NOI represents the net operate income which can be the current rent or the forecasted rent. In this model the capitalization rate is the difference between $Y$ or discount rate and the $g$ factor or growth factor. In real estate standards is indicated as $\Delta a$ and represents the rate of growth both in term of rent and in term of property value ${ }^{2}$.

In fact it has been stressed that it is an "...adjustment rate that reflects the total change or growth in income and value..." (Appraisal Institute 2008). $\Delta a$ or g-term is a product between a rate of change $\Delta$ and a sinking fund factor $a$ (or recapture rate) to convert the total relative change referred to the remaining economic life in income and value into a periodic rate of change. In the cyclical capitalization the rate of change $\Delta a$ assumes a different meaning. It reflects the total change or growth in income and value in the single phase of the property market cycle. For example the formula 3 considers the $\Delta a$ determination in a phase of recovery recession $(\mathrm{RR})$ :

$$
\Delta_{R R} a_{R R}=\Delta_{R R} \frac{Y}{(1+Y)^{t}-1} .
$$

In the formula $3 \Delta_{R R} a_{R R}$ is the product between the rate of change in the phase of recovery recession and the sinking fund factor for the temporal length of the phase $t$ of the recovery recession phase. In the same formula $Y$ is the discount rate.

\footnotetext{
$\overline{2}$ Appraisal Institute 2008: 532.
}

In the application of these models, appraiser must select an appropriate holding period to observe and calculate the rates of change in the single real estate market phases. This holding period looks at the past instead of looking at the future like in the usual application of the Discount Cash Flow Analysis. In the application of Discount Cash Flow Analysis holding period is normally determined according to the following criteria " (a) where cash flows are likely to fluctuate, the length of time for which changes in the cash flows can be reasonably predicted (b) the length of time to enable the business or asset to achieve a stabilised level of earnings (c) the life of the asset (d) the intended hold period of the asset" (IVSC 2012, Technical Information Paper 1 para 7): In this interval the valuer will discount the income stream. A direct capitalization using the model indicated in the formula 1 or in the formula 2 will be summed to the income streams at the end of the holding period. This value is normally defined in several ways: scrap value, exit value, terminal value. In the proposed application of cyclical capitalization an analysis of time series may be useful to observe the temporal length of the phases and the rate of change in the market rent. For this reason it has been defined as backward holding period (d'Amato 2015). Holding period means that the appraiser will select a temporal interval to observe the cycle in the past. This definition is taken from the Discount Cash Flow Analysis. In the Discount Cash Flow Analysis the holding period is a temporal forecast of future rent and cost before selling the exit value determination. In Cyclical Capitalization the holding period describes the temporal interval on which is based the analysis of the upturn and downturn in the real estate market cycle. In order to distinguish the two concepts the holding period used in the cyclical capitalization is defined backward. This happens because it is referred to past income revenues of the property to be estimated.

Cyclical capitalization assumes two g-factors $(\Delta a)$ according to different phases of the market cycle. Following a definition of property market cycle (Mueller, Laposa 1994), it is possible to distinguish two different property market cycle phases: the former is negative and can be called for this study recession-recovery (-) whilst the latter is positive and can be called expansion-contraction (+). Assuming that a complete cycle is composed by a negative phase of recession recovery (-) and a positive phase of expansion contraction (+), the opinion of value will be the result of the sum of different 
"intervals" or alternative phases having different $g$-factors or $\Delta a$ rates of changes. The value will be determined as indicated in the formula 4 in a phase of recession recovery (-) whose length is $t_{r r}$ :

$$
V_{\text {PhaseRR }}=\frac{N O I}{Y-\Delta a_{R R}}-\frac{N O I}{Y-\Delta a_{R R}} \frac{1}{(1+Y)^{t r r}} .
$$

The value of the property in the first cycle composed by two phases considering a second phase of expansion contraction $(+)$ will be:

$$
\begin{aligned}
& V_{\text {PhaseRR }+ \text { PhaseEC }}=\frac{N O I}{Y-\Delta a_{R R}}-\frac{N O I}{Y-\Delta a_{R R}} \frac{1}{(1+Y)^{t r r}}+ \\
& \frac{N O I}{Y-\Delta a_{E C}} \frac{1}{(1+Y)^{t r r}}+-\frac{N O I}{Y+\left(-\Delta a_{E C}\right)} \frac{1}{(1+Y)^{t e c+t r r}} .
\end{aligned}
$$

In the formula $5 t_{R R}$ means the temporal length of recovery recession phase, whilst $t_{E C}$ means the temporal length of expansion contraction phase. Assuming an equal temporal length of phases $t_{r r}$ and $t_{e c}=n$ it is possible to write the formula 6 :

$$
\begin{aligned}
& V=\frac{N O I}{Y-\Delta_{R R} a_{R R}}\left(1+\frac{1}{(1+Y)^{2 n}}+\frac{1}{(1+Y)^{4 n}}+\frac{1}{(1+Y)^{6 n}} \ldots\right)- \\
& \frac{N O I}{Y-\Delta_{R R} a_{R R}}\left(\frac{1}{(1+Y)^{n}}+\frac{1}{(1+Y)^{3 n}}-\frac{1}{(1+Y)^{5 n}} \ldots\right)+ \\
& \frac{N O I}{Y-\Delta_{E C} a_{E C}}\left(\frac{1}{(1+Y)^{n}}+\frac{1}{(1+Y)^{3 n}}-\frac{1}{(1+Y)^{5 n}} \ldots\right)- \\
& \frac{N O I}{Y-\Delta_{E C} a_{E C}}\left(\frac{1}{(1+Y)^{2 n}}+\frac{1}{(1+Y)^{4 n}}-\frac{1}{(1+Y)^{6 n}} \ldots\right) .
\end{aligned}
$$

In the formula 6 it is possible to see 4 infinitive geometric progressions of rate " $r=1 /(1+Y)^{2 n}$ ". When the addition rate of an infinitive geometric progression is included in the following interval $-1<r<1$, the progression will tend to the following formula:

$$
\sum_{i=1}^{\infty} r_{i}=\frac{1}{1-r}, \text { where: } r=\frac{1}{(1+Y)^{2 n}} .
$$

This condition occurs in our case and the value of the perpetuity will be calculated as in the formula 8:

$$
V=\frac{N O I(1+Y)^{n}}{(1+Y)^{n}+1}\left[\frac{1}{Y-\Delta a_{R R}}+\frac{1}{Y-\Delta a_{E C}} \frac{1}{(1+Y)^{n}}\right] .
$$

In the formula 8 NOI is the Net Operate Income, there are two different $g$-factors or $\Delta a$ terms. The former is related to recovery recession phase, the latter is related to the expansion contraction phase. In the formula $8, Y$ is the discount rate and $n$ is the temporal length of the two phases of the property market cycle. They are supposed equal. The formula can be applied in this version to freehold properties. In the same primum group there are also other models that can be applied to leasehold properties.

Having two different g-factors $(\Delta a)$ the model will use two different overall capitalization rates according to the different market phases. The former related to the recovery recession phase will be the result of the following difference:

$$
R_{R R}=Y-\left(-\Delta a_{R R}\right)
$$

The latter will be the result of the following difference:

$$
R_{E C}=Y-\left(+\Delta a_{E C}\right)
$$

The same approach could be applied using the direct capitalization model showed in the formula 1. In this case there will be a constant Net Operate Income per each real estate market phase. Therefore it will be possible to write:

$$
V=\frac{N O I(1+Y)^{n}}{(1+Y)^{n}+1}\left[\frac{1}{R_{R R}}+\frac{1}{R_{E C}} \frac{1}{(1+Y)^{n}}\right]
$$

Table 1. Comparison between direct capitalization and cyclical capitalization (primum group)

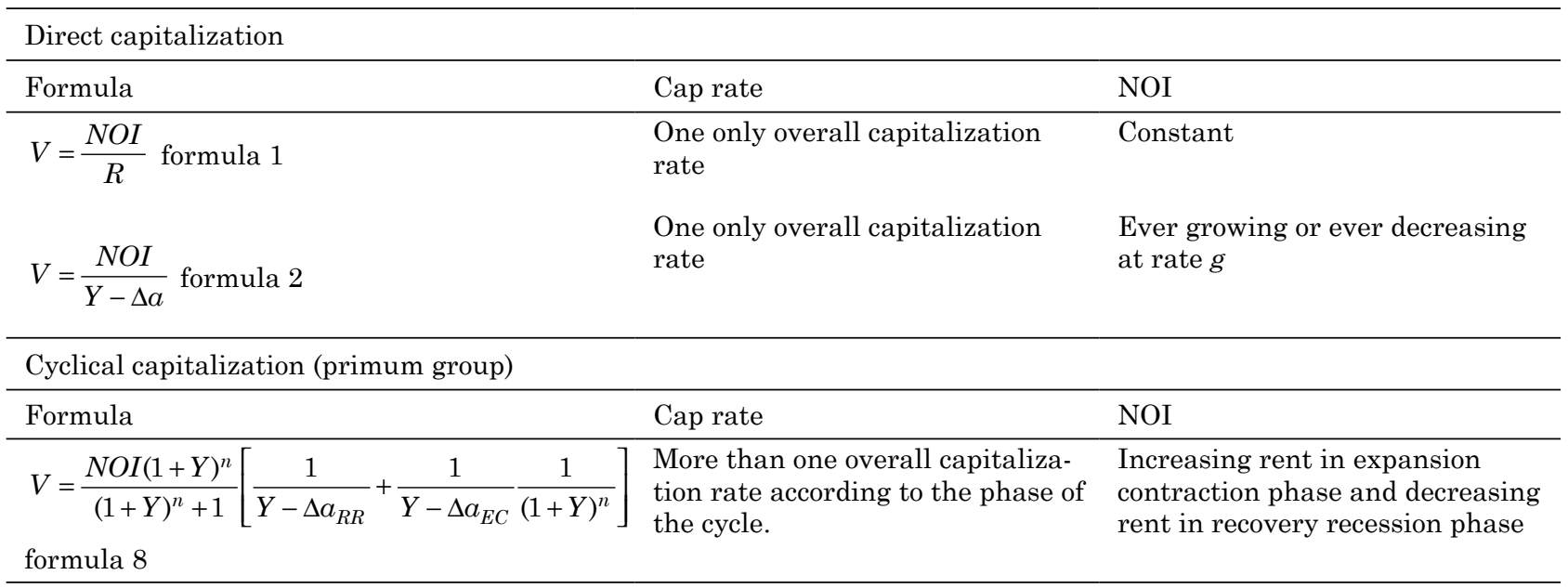


In the formula $1 \mathrm{NOI}$ is the Net Operate Income, $Y$ is the discount rate, $R_{R R}$ is the overall capitalization rate in the recovery recession phase whilst $R_{E C}$ is the overall capitalization rate in the expansion contraction phase of the market. In this case the cap rate does not consider a growth factor $\mathrm{g}$ or $\Delta a$ and may be determined through a market extraction method or survey. In the Table 1 it is possible to observe a comparison between the different models of direct capitalization considered in this paragraph.

A relationship between direct and cyclical capitalization will be shown in the following paragraph.

\section{DIRECT CAPITALIZATION AND CYCLICAL CAPITALIZATION}

Cyclical capitalization is clearly different from the models of direct capitalization indicated in the formulas 1 and 2. Cyclical capitalization models assume a real estate rent increasing or decreasing according to a regular real estate market phase like in the formula 8 . The property market Net Operate Income may varies only between the two property market phases as in the formula 11 . In the direct capitalization models, Net Operate Income are ever growing or ever decreasing at a grate like in the formula 2 . Net Operate Income can be also supposed constant like in the formula 1 . The following figures highlight the relationship between Net Operate Income and the time in these models. In the $y$-axis it is possible to observe the euro measuring Net Operate Income, whilst in the $x$-axis is indicated the time. In the Figure 1 the relationship between Net Operate Income and time is shown applying the direct capitalization as in the formula 1.

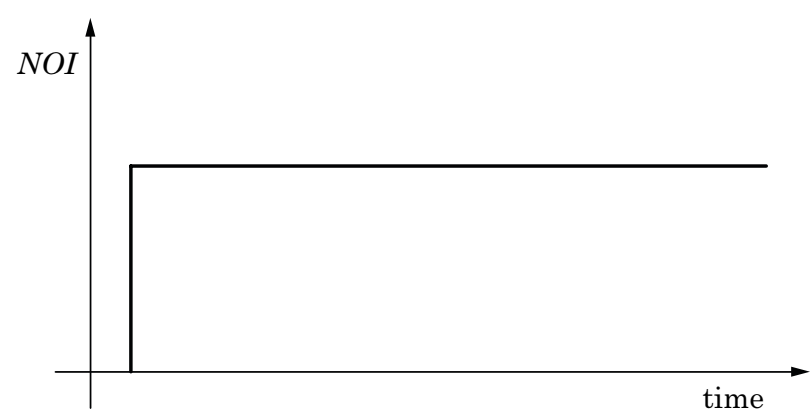

Fig. 1. Direct capitalization based on the direct capitalization (formula 1)
In the Figure 1 the Net Operate Income it is supposed to be constant over time. In the Figure 2 it is described the relationship between time and Net Operate Income in the direct capitalization based on the Dividend Discount Model indicated in the formula 2 .

In this case the opinion of value is based on the assumption of a Net Operate Income ever growing or ever decreasing at a $g$-rate or $\Delta a$ rate (considering $Y>\Delta a$ ). These are the ways the appraiser deals with the future when delivering an opinion of value based on income approach. Even in the application of a Discount Cash Flow Analysis at the end of the holding period the appraiser calculate a terminal value or scrap value or exit value based on the relationship indicated in the Figure 1 or in the Figure 2. A question can be raised observing both these figures: Do these figures represents the reality? Is this what actually happens in the market? The reality seems to be quite different. The sample considered in the empirical application demonstrates that property rent varies according to the market cycle. As a consequence the figure described by the Figures 1 and 2 are distant from the reality. Figure 3 shows the behaviour of a Net Operate Income in the different income approach of cyclical capitalization.

In this case the opinion of value is based on the assumption of a Net Operate Income increasing at $a+g_{E C}$ or $+\Delta a_{E C}$ rate in the expansion contraction phase of the real estate market and decreasing at $a-g_{R R}$ or $-\Delta a_{R R}$ rate in the recovery recession phases of the market. The Net Operate Income will increase and decrease during an interval of time equal to $n$. In the Figure 4 it is possible to observe the second model of cyclical capitalization presented in the formula 11. A usual the figure will describe the relationship between Net Operate Income and time.

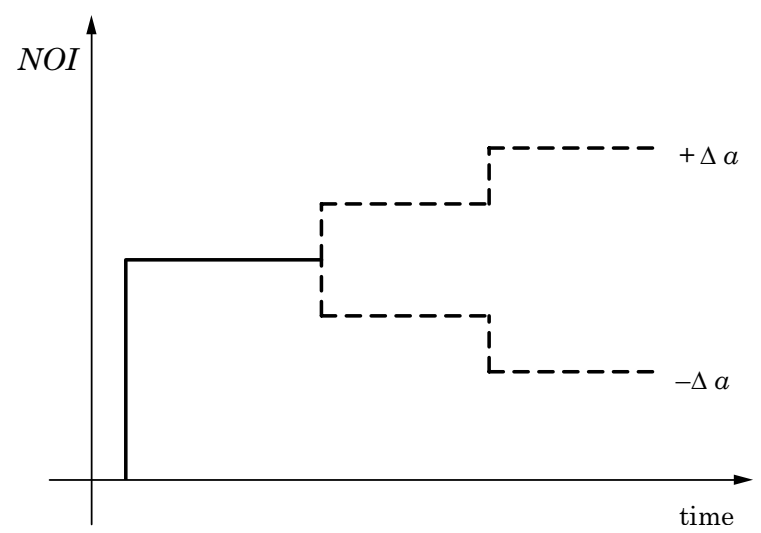

Fig. 2. Direct capitalization based on the dividend discount model (formula 2) 


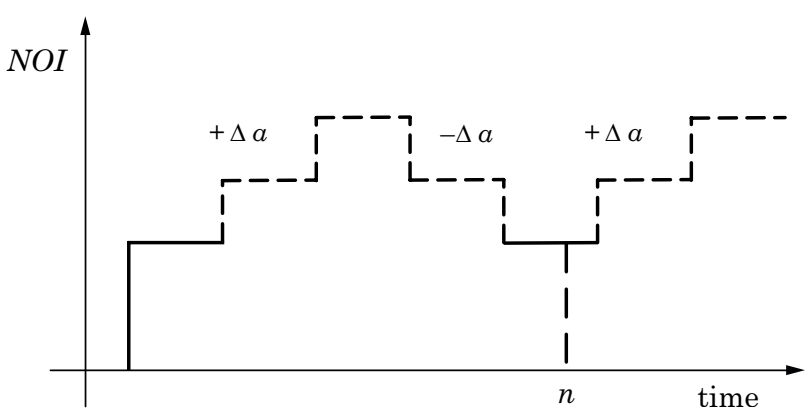

Fig. 3. Direct capitalization based on cyclical capitalization (formula 8)

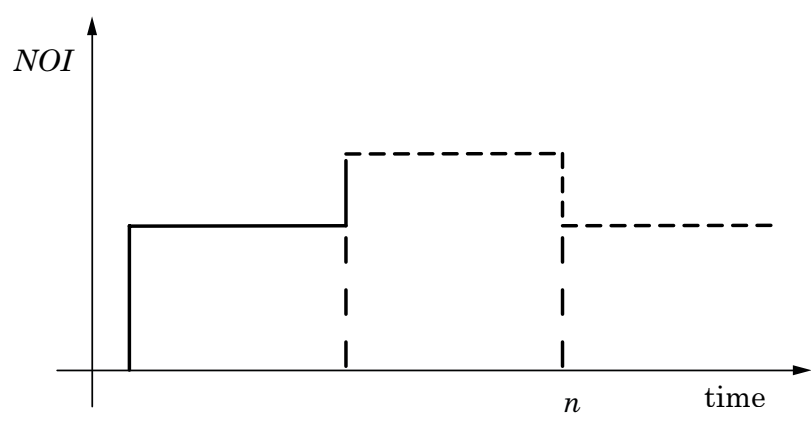

Fig. 4. Direct capitalization based on cyclical capitalization (formula 11)

It is worth to notice that in the Figure 4 the Net Operate Income of the property does not increase or decrease during the phase of the real estate market cycle. Net Operate Income varies among the phases and does not vary inside the single phase. Both in the Figures 3 and 4, the opinion of value is based on the sum of different intervals whose Net Operate Income is constant. The Net Operate Income will vary changing the property market phase. The Figures 3 and 4 allow the appraiser to include real estate market trends analysis in the valuation process of an income producing property. Obviously these models can be used also to provide a terminal value in the application of a two stage model or a hardcore model (Scarrett 1990). They may be also used to define the exit value in the Discount Cash Flow Analysis both in real property and in trade related properties valuations (d'Amato, Kauko 2012a). These methods may be helpful to deal with the future trends of the property market cycles in a more realistic way. A property market rent rarely behaves as indicated in the Figure 1 (always constant) and in the Figure 2 (ever increasing or decreasing).

In this paper only two models (among more than thirteen) have been highlighted and the choice of the right model to apply is depending on the nature, the characteristics of the property market cycle. In some cases may be appropriate to apply the formula 11 if there are small variations inside the cycle and great variation between the two phases of the cycle. In other cases may be helpful the application of the formula 8 where both the variation inside the phases of the cycle and the variation between the different phases of the cycle are meaningful.

\section{AN APPLICATION OF CYCLICAL CAPITALIZATION}

Cyclical capitalization has been applied to London market of Eastern London (d'Amato, Kauko 2012b) using a time series of prime rent in the office sector. The data regarding a time series of prime rent from the $3^{\text {rd }}$ quarter of 1972 to $1^{\text {st }}$ quarter 2008 are particularly important because consider more than 20 years before the 2008 crisis. They have been provided by CB Richard Ellis London. They are referred to office market freehold properties in prime location. The data are appraisal based. These appraisals are based on an analysis of real transactions occurred in the area and are referred to an office unit of standard size of 1000 sq.m. of highest quality and specification. It is also assumed that the blue chip occupier agree with a package of incentives that is typical for the market at the time. The components of a time series are Trends, Cyclical, Seasonal and Erratic. In order to detect the rate of change $\Delta$ in the single phases of the cycle the attention was focused on the prime rent. The rate of change in the time series taken into account will be calculated as indicated in the formula 12 :

$$
\Delta=\frac{R_{t+1}-R_{t}}{R_{t}}
$$

The rate of change was calculated for each period of the time series of prime rent of the office market in the area Eastern London of the city of London ${ }^{3}$.

The rate of change of rent was the only information available. The meaning of $\Delta$ is a rate of change reflecting the variation term both of rent and value. Unfortunately only the data about prime rent are available and this application of the cyclical capitalization is based on the assumption of a rate of change of rent meaningful for the future changes in terms of value, too. In particular, the attention is focused on the last 12 years that is

\footnotetext{
3 The author is grateful to Mark Charlton of CBRE London for providing the data.
} 


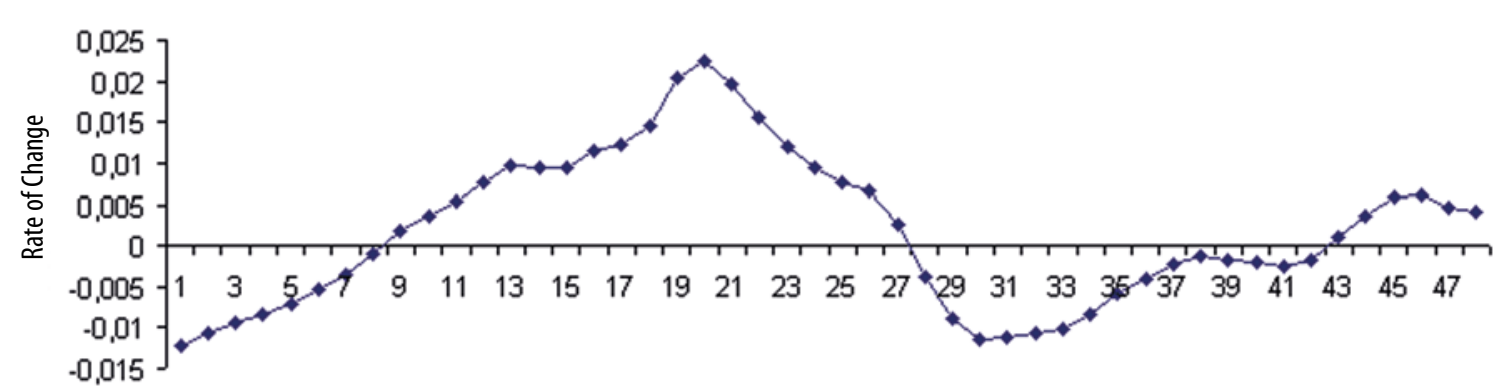

Number of Trimester

Fig. 5. Prime rent in the London office market in Eastern London The data have been provided by CB Richard Ellis London

the selected backward holding period in this case. The cyclical component of the time series was isolated using an ARIMA model applied to the original time series. The Figure 5 shows the following final result.

In the Figure 5 the cyclical component was isolated using GRETL software. The Dickey Fuller test is 0,5992. The Durbin Watson test is 1.9979. Therefore the errors are not correlated. ARIMA models are an integration between autoregressive models and moving average models. They have been applied several times to real estate markets. Among the others they have been applied in Hong Kong (Tse 1997). These models have been used to examine UK office market (McCough, Tsolacos 1995) ARIMA models have been compared with OLS and VAR based models (Stevenson, McGrath 2003).

In the Figure 1 is possible to see three main phases. The first one is a growing phase (expansion contraction, + phase), the second is a decreasing phase (recovery recession, - phase) and then a third growing (expansion contraction, + phase). In the Table 2 it is possible to observe the number of quarters composing each phase.

Table 2. Temporal length of the phases

\begin{tabular}{llll}
\hline Phases & & & \\
\cline { 1 - 3 } $\mathrm{I}^{\text {st }}$ phase & $\mathrm{II}^{\text {nd }}$ phase & $\mathrm{III}^{\mathrm{rd}}$ phase & \\
\cline { 1 - 3 }+ & - & + & 4 \\
\hline 16 & 16 & 17 & 4 \\
\hline
\end{tabular}

The first growing phase is indicate with a plus (expansion contraction, +) having a temporal length of 16 quarters. The second decreasing phase is indicate with a minus (recovery recession, -) having a temporal length of 16 quarters, whilst the third increasing phase indicated with a plus (ex- pansion contraction) having a temporal length of 17 quarters. The analysis is essential to define the term $\mathrm{n}$ in the formula 8 and 11. In the backward holding period the time series shows two different phases of expansion contraction (+). The former is 16 quarters and the latter is 17 quarters. There is one only recovery recession (-) phase whose length is similar: 16 quarters. The assumption of this model $n=t_{R R}=t_{E C}$ can be considered realistic. Assuming 16 quarter as medium length $\mathrm{n}$ of a single phase of the cycle it will be equivalent to 4 years. In the Table 3 there is the calculation of percentage change of the prime rent $\Delta$ both quarterly and annual. This is related to the specific phase of the market.

Table 3. $\Delta$ rate of change

\begin{tabular}{llll}
\hline & $\Delta$ & & \\
\cline { 2 - 4 } & + & - & + \\
\hline Trimestral & 0.01 & -0.002474 & 0.001490182 \\
Annual & 0.0404 & -0.00986 & 0.005974064 \\
\hline
\end{tabular}

The quarterly rate of change will be transformed in an annual rate of change using the following formula 13 in the expansion contraction phase:

$$
\Delta_{E C}=(1+0.009956)^{4}-1=0.040421 .
$$

The quarterly rate of change will be transformed in an annual rate of change using the following formula 14 in the recovery recession phase:

$$
\Delta_{R R}=(1-0.002474)^{4}-1=-0.00986 .
$$

As one can see there is a substantially equally length of the phase. The rate of change of the phase of expansion contraction is quite different from the rate of change of the phase of recovery recession. In the former the annual rate of change 
is equal to 0.040421 whist in the latter the rate of change will be -0.005974064 . As a consequence it is not possible the application of the cyclical capitalization model indicated in the formula 11 and described by the Figure 4. Especially in the expansion contraction phase, the rent presents a growing factor different from 0 . Therefore the cyclical capitalization model selected will be the one indicated in the formula 8 and described by the Figure 3.

In order to observe the variability of the opinion of value it has been considered a Net Operate Income equal to 1 and the discount rate $\mathrm{Y}$ varying between a minimum of 0.055 and a maximum of 0.15 .The overall capitalization rate in the recovery recession will vary according to the variation of discount rate. The recovery recession (-) phase can be calculated as indicated in the Table 4 .

In the Table 4 the second column Y indicates the discount rate which varies between a minimum of 0.055 and a maximum of 0.15 . The third column indicates the rate of change of recovery recession phase $\Delta_{R R}$ calculated on the time series using the formula 10 , the fourth column is the calculation of the sinking fund factor $a$ calculated like in the second part of the formula 3 . The fifth column is the product of the rate of change $\Delta_{R R}$ for the specific market phase by the sinking fund factor $a_{R R}$. This product was described by the formula 3. The sixth column is referred to the calculation of overall capitalization rate in the recovery recession phase as indicated in the formula 8 . The last column indicated the length of the phase equal to 4 years. The overall capitalization rate in the expansion contraction (+) phase is calculated in the Table 5. It will vary according to the variation of discount rate applying the formula 3 .

In the Table 5 the second column $\mathrm{Y}$ indicates the discount rate which varies between a minimum of 0.055 and a maximum of 0.15 . The third column indicates the rate of change $\Delta_{E C}$ in the expansion contraction phase calculated on the time series using the formula 12 . It will be the mean between the two rates of change observed in the two positive-expansion contraction phases of the market. These rates of change have been indicated in the Table 3. The fourth column is the calculation of the sinking fund factor $a_{E C}$ of expansion contraction phase calculated as in the second part of the formula 3 . The fifth column is the product of the rate of change $\Delta_{E C}$ of the specific market phase by the sinking fund factor $a_{E C}$. This product was described by the formula 3 . The sixth column is referred to calculation of overall capitalization rate in the expansion contraction phase as indicated in the formula 10. The last column indicated the length of the phase equal to 4 . Having both the overall cap rates will be easy the application of the cyclical capitalization model indicated in the formula 8 . The application will assume $n$ (the

Table 4. Calculation of overall cap rate in the recovery recession $(-)$ phase

\begin{tabular}{|c|c|c|c|c|c|c|}
\hline & \multicolumn{6}{|c|}{ Recession recovery phase } \\
\hline & $Y$ & $\begin{array}{l}\text { Rate of change } \\
\Delta\end{array}$ & Sinking fund factor $a$ & $\Delta a$ & $R r r$ & $t$ (years) \\
\hline 1 & 0.15 & -0.009859833 & 0.200265352 & -0.001974583 & 0.151974583 & 4 \\
\hline 2 & 0.145 & & 0.201728872 & -0.001989013 & 0.146989013 & \\
\hline 3 & 0.14 & & 0.203204783 & -0.002003565 & 0.142003565 & \\
\hline 4 & 0.135 & & 0.20469319 & -0.002018241 & 0.137018241 & \\
\hline 5 & 0.13 & & 0.206194197 & -0.00203304 & 0.13203304 & \\
\hline 6 & 0.125 & & 0.207707911 & -0.002047965 & 0.127047965 & \\
\hline 7 & 0.12 & & 0.209234436 & -0.002063017 & 0.122063017 & \\
\hline 8 & 0.115 & & 0.210773881 & -0.002078195 & 0.117078195 & \\
\hline 9 & 0.11 & & 0.212326352 & -0.002093502 & 0.112093502 & \\
\hline 10 & 0.105 & & 0.213891956 & -0.002108939 & 0.107108939 & \\
\hline 11 & 0.1 & & 0.215470804 & -0.002124506 & 0.102124506 & \\
\hline 12 & 0.095 & & 0.217063002 & -0.002140205 & 0.097140205 & \\
\hline 13 & 0.09 & & 0.218668662 & -0.002156036 & 0.092156036 & \\
\hline 14 & 0.085 & & 0.220287893 & -0.002172002 & 0.087172002 & \\
\hline 15 & 0.08 & & 0.221920804 & -0.002188102 & 0.082188102 & \\
\hline 16 & 0.075 & & 0.223567509 & -0.002204338 & 0.077204338 & \\
\hline 17 & 0.07 & & 0.225228117 & -0.002220712 & 0.072220712 & \\
\hline 18 & 0.065 & & 0.22690274 & -0.002237223 & 0.067237223 & \\
\hline 19 & 0.06 & & 0.228591492 & -0.002253874 & 0.062253874 & \\
\hline 20 & 0.055 & & 0.230294485 & -0.002270665 & 0.057270665 & \\
\hline
\end{tabular}


Table 5. Calculation of overall cap rate in the expansion contraction $(+)$ phase

\begin{tabular}{|c|c|c|c|c|c|c|}
\hline & \multicolumn{6}{|c|}{ Expansion contraction phase } \\
\hline & $\mathrm{Y}$ & Rate of change $\Delta$ & Sinking fund factor $\alpha$ & $\Delta \alpha$ & $\operatorname{Rec}$ & $\mathrm{t}$ (years) \\
\hline 1 & 0.15 & 0.023197733 & 0.200265352 & 0.004645702 & 0.145354298 & 4 \\
\hline 2 & 0.145 & & 0.201728872 & 0.004679652 & 0.140320348 & \\
\hline 3 & 0.14 & & 0.203204783 & 0.00471389 & 0.13528611 & \\
\hline 4 & 0.135 & & 0.20469319 & 0.004748418 & 0.130251582 & \\
\hline 5 & 0.13 & & 0.206194197 & 0.004783238 & 0.125216762 & \\
\hline 6 & 0.125 & & 0.207707911 & 0.004818353 & 0.120181647 & \\
\hline 7 & 0.12 & & 0.209234436 & 0.004853765 & 0.115146235 & \\
\hline 8 & 0.115 & & 0.210773881 & 0.004889476 & 0.110110524 & \\
\hline 9 & 0.11 & & 0.212326352 & 0.00492549 & 0.10507451 & \\
\hline 10 & 0.105 & & 0.213891956 & 0.004961808 & 0.100038192 & \\
\hline 11 & 0.1 & & 0.215470804 & 0.004998434 & 0.095001566 & \\
\hline 12 & 0.095 & & 0.217063002 & 0.00503537 & 0.08996463 & \\
\hline 13 & 0.09 & & 0.218668662 & 0.005072617 & 0.084927383 & \\
\hline 14 & 0.085 & & 0.220287893 & 0.00511018 & 0.07988982 & \\
\hline 15 & 0.08 & & 0.221920804 & 0.00514806 & 0.07485194 & \\
\hline 16 & 0.075 & & 0.223567509 & 0.005186259 & 0.069813741 & \\
\hline 17 & 0.07 & & 0.225228117 & 0.005224782 & 0.064775218 & \\
\hline 18 & 0.065 & & 0.22690274 & 0.005263629 & 0.059736371 & \\
\hline 19 & 0.06 & & 0.228591492 & 0.005302804 & 0.054697196 & \\
\hline 20 & 0.055 & & 0.230294485 & 0.00534231 & 0.04965769 & \\
\hline
\end{tabular}

Table 6. Calculation of opinion of value with cyclical capitalization

\begin{tabular}{llllll}
\hline & $\mathrm{Y}$ & Rrr & Rec & $\mathrm{t}$ & $\mathrm{V}$ \\
\hline 1 & 0.15 & 0.151974583 & 0.145354298 & 4 & 6.689066652 \\
2 & 0.145 & 0.146989013 & 0.140320348 & 6.922150503 \\
3 & 0.14 & 0.142003565 & 0.13528611 & 7.172114024 \\
4 & 0.135 & 0.137018241 & 0.130251582 & 7.440862071 \\
5 & 0.13 & 0.13203304 & 0.125216762 & 7.730597619 \\
6 & 0.125 & 0.127047965 & 0.120181647 & 8.043882526 \\
7 & 0.12 & 0.122063017 & 0.115146235 & 8.383713806 \\
8 & 0.115 & 0.117078195 & 0.110110524 & 8.753620247 \\
9 & 0.11 & 0.112093502 & 0.10507451 & 9.157786 \\
10 & 0.105 & 0.107108939 & 0.100038192 & 9.601210372 \\
11 & 0.1 & 0.102124506 & 0.095001566 & 10.08991686 \\
12 & 0.095 & 0.097140205 & 0.08996463 & 10.6312301 \\
13 & 0.09 & 0.092156036 & 0.084927383 & 11.23414803 \\
14 & 0.085 & 0.087172002 & 0.07988982 & 11.90984984 \\
15 & 0.08 & 0.082188102 & 0.07485194 & 12.67240143 \\
16 & 0.075 & 0.077204338 & 0.069813741 & 13.53975451 \\
17 & 0.07 & 0.072220712 & 0.064775218 & 14.53519284 \\
18 & 0.065 & 0.067237223 & 0.059736371 & 15.6894793 \\
19 & 0.06 & 0.062253874 & 0.054697196 & 17.04413614 \\
20 & 0.055 & 0.057270665 & 0.04965769 & 18.65662787 \\
\hline & & & &
\end{tabular}

temporal length of the phase) equal to 4 years in both phases and Net Operate Income equal to 1.

In the Table 6 the second column Y indicates the discount rate which varies between the 0.055 and the 0.15 , the third column indicates the overall capitalization rate in the recovery recession phase of the market previously calculated in the Table 4. The fourth column indicates the overall capitalization rate in the expansion contraction phase of the cycle previously calculated in the Table 5 . The fifth column indicates the length of the phase of 4 years, whilst the last column indicates the opinion of value applying the cyclical capitalization model indicated in the formula 8.

The Table 7 compares the opinion of value derived from the cyclical capitalization by the opinion of value derived from the application of the traditional dividend discount model using the overall capitalization rate of the recovery recession (-) phase and by the traditional dividend discount model using the overall capitalization rate of the expansion contraction phase (+).

In the Table 7 the second column there is the discount rate $Y$ varying between 0.055 and 0.15 . The third column indicates the value derived from the application of cyclical capitalization models indicated in the formula 8 assuming a Net Operate Income equal to 1 . The fourth and the fifth columns indicate the opinion of value based on the traditional dividend discount model. In the fourth column the Net Operate Income is equal to 1 and the overall capitalization rate is derived from the recovery recession phase applying the formula 9 . In the fifth column the Net Operate Income is equal to 1 and the overall capitalization rate is derived from the expansion contraction phase using the formula 10. The sixth column calculates the differences between the opinion of value provided by the application of cyclical capitalization $V_{C C}$ and the opinion of value based on traditional dividend discount model 
Table 7. Comparison between DD models and cyclical capitalization

\begin{tabular}{lllllll}
\hline & $Y$ & $V c c$ & $V r r$ & $V e c$ & $V e c-V c c$ & $V c c-V r r$ \\
\hline 1 & 0.15 & 6.689066652 & 6.58004767 & 6.879741532 & 0.19067488 & 0.109018981 \\
2 & 0.145 & 6.922150503 & 6.803229575 & 7.126550194 & 0.204399692 & 0.118920928 \\
3 & 0.14 & 7.172114024 & 7.042076716 & 7.391741857 & 0.219627832 & 0.130037308 \\
4 & 0.135 & 7.440862071 & 7.298298354 & 7.677449932 & 0.236587861 & 0.142563718 \\
5 & 0.13 & 7.730597619 & 7.573861798 & 7.98615124 & 0.255553621 & 0.156735822 \\
6 & 0.125 & 8.043882526 & 7.871043018 & 8.320737997 & 0.276855471 & 0.172839508 \\
7 & 0.12 & 8.383713806 & 8.192489652 & 8.684608715 & 0.300894909 & 0.191224154 \\
8 & 0.115 & 8.753620247 & 8.541300096 & 9.081784058 & 0.32816381 & 0.212320152 \\
9 & 0.11 & 9.157786 & 8.921123699 & 9.517056036 & 0.359270036 & 0.236662301 \\
10 & 0.105 & 9.601210372 & 9.336288923 & 9.996182303 & 0.394971931 & 0.264921449 \\
11 & 0.1 & 10.08991686 & 9.791969022 & 10.52614229 & 0.436225429 & 0.297947838 \\
12 & 0.095 & 10.6312301 & 10.29439871 & 11.11547944 & 0.484249336 & 0.33683139 \\
13 & 0.09 & 11.23414803 & 10.85116112 & 11.7747653 & 0.54061727 & 0.382986904 \\
14 & 0.085 & 11.90984984 & 11.47157321 & 12.51723932 & 0.60738948 & 0.438276629 \\
15 & 0.08 & 12.67240143 & 12.16721126 & 13.35970709 & 0.687305658 & 0.505190177 \\
16 & 0.075 & 13.53975451 & 12.95264 & 14.32382781 & 0.784073301 & 0.587114503 \\
17 & 0.07 & 14.53519284 & 13.84644347 & 15.43800277 & 0.902809928 & 0.688749371 \\
18 & 0.065 & 15.6894793 & 14.87271416 & 16.74022016 & 1.050740863 & 0.816765136 \\
19 & 0.06 & 17.04413614 & 16.06325739 & 18.28247295 & 1.238336815 & 0.980878744 \\
20 & 0.055 & 18.65662787 & 17.46094616 & 20.13786784 & 1.481239975 & 1.195681709 \\
\hline & & & & & & \\
\hline
\end{tabular}

Table 8. Comparison between the DD model in expansion contraction phase of the market and cyclical capitalization for different temporal lengths of the market phase

\begin{tabular}{|c|c|c|c|c|c|c|c|}
\hline & & $V e c-V c c$ & & & & & \\
\hline & $Y$ & $t=4$ & $t=7$ & $t=9$ & $t=11$ & $t=13$ & $t=15$ \\
\hline 1 & 0.15 & 0.15468309 & 0.255122017 & 0.334272747 & 0.140794361 & 0.123763638 & 0.1072038 \\
\hline 2 & 0.145 & 0.166045226 & 0.274109961 & 0.359419162 & 0.153656324 & 0.136025092 & 0.118717928 \\
\hline 3 & 0.14 & 0.178657474 & 0.295179839 & 0.387323356 & 0.168029669 & 0.149788363 & 0.131712317 \\
\hline 4 & 0.135 & 0.192709748 & 0.318648314 & 0.41840503 & 0.184146028 & 0.16528643 & 0.146421108 \\
\hline 5 & 0.13 & 0.208429494 & 0.344895097 & 0.453167861 & 0.202282776 & 0.182798251 & 0.16312474 \\
\hline 6 & 0.125 & 0.226090952 & 0.37437871 & 0.492220672 & 0.222774357 & 0.202660123 & 0.182161361 \\
\hline 7 & 0.12 & 0.246027219 & 0.407657048 & 0.536305115 & 0.246027036 & 0.225280468 & 0.203941663 \\
\hline 8 & 0.115 & 0.268646094 & 0.445414513 & 0.586332303 & 0.272538303 & 0.251159294 & 0.228968412 \\
\hline 9 & 0.11 & 0.294451143 & 0.488498214 & 0.64343183 & 0.302922708 & 0.280914093 & 0.257862421 \\
\hline 10 & 0.105 & 0.324070034 & 0.537966902 & 0.709018257 & 0.337946663 & 0.31531473 & 0.291397536 \\
\hline 11 & 0.1 & 0.358293166 & 0.595158017 & 0.78488257 & 0.378575976 & 0.355331094 & 0.330548423 \\
\hline 12 & 0.095 & 0.398127104 & 0.661780975 & 0.873319962 & 0.42604173 & 0.402199141 & 0.376556771 \\
\hline 13 & 0.09 & 0.444869678 & 0.740049128 & 0.977311497 & 0.481933077 & 0.457513925 & 0.431024569 \\
\hline 14 & 0.085 & 0.50021741 & 0.832869943 & 1.100787372 & 0.548330317 & 0.523363008 & 0.496047851 \\
\hline 15 & 0.08 & 0.56642222 & 0.94412477 & 1.249016709 & 0.62799957 & 0.60252165 & 0.574412394 \\
\hline 16 & 0.075 & 0.646525081 & 1.07909006 & 1.42919879 & 0.724684003 & 0.698744808 & 0.669886475 \\
\hline 17 & 0.07 & 0.744713081 & 1.245088364 & 1.651384766 & 0.843550534 & 0.817215075 & 0.787670019 \\
\hline 18 & 0.065 & 0.866880526 & 1.452524882 & 1.929960344 & 0.991894896 & 0.965249743 & 0.935103624 \\
\hline 19 & 0.06 & 1.021539271 & 1.7165956 & 2.286119058 & 1.180291437 & 1.153453982 & 1.122825062 \\
\hline 20 & 0.055 & 1.221351209 & 2.060216968 & 2.752167309 & 1.424540626 & 1.397674292 & 1.366728574 \\
\hline
\end{tabular}

indicated in the fifth column $\left(V_{E C}\right)$. The seventh column calculates the differences between the opinion of value provided by the application of cyclical capitalization $V_{C C}$ and the opinion of value based on traditional dividend discount model indicated in the fourth column $\left(V_{R R}\right)$. The sixth and the seventh columns demonstrate that the values provided by the application of cyclical capitalization are always between the $V_{R R}$ (value in recovery recession phase) and the $V_{E C}$ (value in expansion contraction phase). The application of the method determines a countercyclical opinion of value. In the Figure 6 the blue line representing the opinion of value based on the cyclical capitalization provides a value included in the interval between the Dividend Discount Model 1 and the Dividend Discount Model 2.

The blue line indicating the value derived from cyclical capitalization is between the pink line of 


\section{Comparison Among DD Models and Cyclical Capitalization Model}

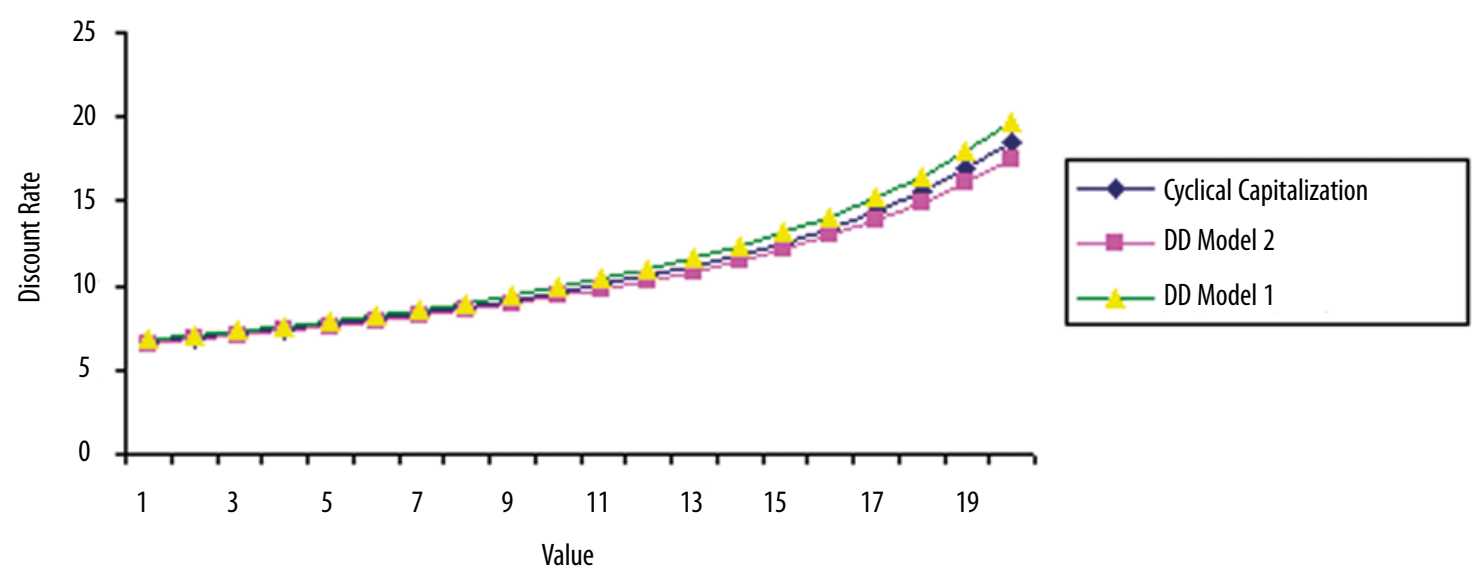

Fig. 6. Comparison among the opinion of value based on the cyclical capitalization and the opinions of value based on the dividend discount models

the DD model 2 and the green line of the DD model 1. The DD model 2 refers to the application of the Dividend Discount model using a $g$-factor or $\Delta_{R R}$ of recovery recession phase of the real estate market, whilst the DD model 1 is an application of Dividend Discount model using a g-factor or $\Delta_{E C}$ of a real estate market phase of expansion contraction. In order to explore the robustness of the model the same difference has been calculated for different lags of time representing the variable $n$ in the formula 8 . The Table 8 shows the difference between the opinion of value based on cyclical capitalization and the valuation based on the traditional Dividend Discount Model 1 using g-factor $\Delta_{E C}$ of an expansion contraction phase $\left(V_{E C}\right)$. This difference is calculated assuming a variation of the temporal length of the phase included in the interval between 4, 7, 9, 11, 13 and 15 years.

The difference between the $\mathrm{V}_{\mathrm{EC}}$ derived from the application of Dividend Discount Model 1 and the value derived by cyclical capitalization is always positive. The Table 9 reports the difference between the opinion of value based on cyclical capitalization and the valuation based on the traditional Dividend Discount Model 2 in a recovery recession phase $\left(V_{R R}\right)$ assuming the same lags of time of Table 8.

Assuming a variation of the temporal length of the phase included in the interval between 4 years and 15 years it is possible to see that the opinion of value provided by the cyclical capitalization is always superior to the value obtained by the application of traditional Dividend Discount Model in a recovery recession phase $\left(V_{R R}\right)$. The comparison seems to be interesting because confirm the countercyclical nature of cyclical capitalization methodology assuming different lags of the time $n$.

\section{FINAL REMARKS AND FUTURE DIRECTIONS OF RESEARCH}

The work proposes the empirical application of a new family of income oriented methodologies defined cyclical capitalization and previously presented as Cyclical Dividend Discount models (d'Amato 2003). The models proposed belong to a wider group of valuation methodologies based on income approach integrating regular and irregular property market cycle analysis in an opinion of value based on the application of income approach.

These models may be particularly useful in the valuation process of income producing properties characterized by a relatively frequent upturn and downturn of the market cycle. They may be also useful to determine the exit value, scrap value, terminal value in a Discount Cash Flow Analysis or in the Two Stage models.

The valuation method has been applied on the office market of Eastern London. The model applied is depending on the characteristics of the real estate market cycle. The final results show that the opinion of value based on the application of cyclical capitalization is less sensitive to property market cycle. The models proposed have some limitations. The first one is the normative and indicative of what the market "should" be willing to pay. It means that market price and rent behaviour may be different from the past. In this case 
Table 9. Comparison between DD model in recovery recession phase and cyclical capitalization for different temporal lengths of the market phase

\begin{tabular}{|c|c|c|c|c|c|c|c|}
\hline & & $V c c-V r r$ & & & & & \\
\hline & $Y$ & $t=4$ & $t=7$ & $t=9$ & $t=11$ & $t=13$ & $t=15$ \\
\hline 1 & 0.15 & 0.109018981 & 0.064960697 & 0.044766086 & 0.030262794 & 0.020115051 & 0.013174756 \\
\hline 2 & 0.145 & 0.118920928 & 0.072230398 & 0.050487198 & 0.034648951 & 0.023396328 & 0.015575213 \\
\hline 3 & 0.14 & 0.130037308 & 0.080502038 & 0.057069193 & 0.03975874 & 0.027271876 & 0.018452432 \\
\hline 4 & 0.135 & 0.142563718 & 0.089947162 & 0.064667287 & 0.045730703 & 0.031863318 & 0.02191118 \\
\hline 5 & 0.13 & 0.156735822 & 0.100773642 & 0.073470506 & 0.052734645 & 0.037320914 & 0.026082138 \\
\hline 6 & 0.125 & 0.172839508 & 0.113235067 & 0.083710578 & 0.060980005 & 0.043831417 & 0.031129233 \\
\hline 7 & 0.12 & 0.191224154 & 0.127643054 & 0.095673601 & 0.070726894 & 0.051628469 & 0.037259379 \\
\hline 8 & 0.115 & 0.212320152 & 0.144383557 & 0.109715545 & 0.08230079 & 0.061006482 & 0.044735527 \\
\hline 9 & 0.11 & 0.236662301 & 0.163938715 & 0.126283071 & 0.096112321 & 0.072339384 & 0.053894367 \\
\hline 10 & 0.105 & 0.264921449 & 0.186916483 & 0.14594182 & 0.11268422 & 0.086106244 & 0.065170598 \\
\hline 11 & 0.1 & 0.297947838 & 0.214091356 & 0.169415399 & 0.13268857 & 0.102926761 & 0.079130664 \\
\hline 12 & 0.095 & 0.33683139 & 0.246461182 & 0.197639872 & 0.156998979 & 0.123611134 & 0.096520302 \\
\hline 13 & 0.09 & 0.382986904 & 0.285327689 & 0.231841183 & 0.186764899 & 0.149231273 & 0.118332641 \\
\hline 14 & 0.085 & 0.438276629 & 0.332412695 & 0.273647124 & 0.223519356 & 0.181224298 & 0.145907461 \\
\hline 15 & 0.08 & 0.505190177 & 0.390029178 & 0.325252515 & 0.269338251 & 0.22154596 & 0.181078743 \\
\hline 16 & 0.075 & 0.587114503 & 0.461338765 & 0.389668364 & 0.327081189 & 0.272903156 & 0.226398865 \\
\hline 17 & 0.07 & 0.688749371 & 0.550749116 & 0.471107207 & 0.400764782 & 0.339115203 & 0.285487863 \\
\hline 18 & 0.065 & 0.816765136 & 0.664544936 & 0.575596265 & 0.496157968 & 0.425691319 & 0.363593092 \\
\hline 19 & 0.06 & 0.980878744 & 0.811923179 & 0.711985448 & 0.621762805 & 0.540784237 & 0.468515668 \\
\hline 20 & 0.055 & 1.195681709 & 1.006756796 & 0.893668272 & 0.790492554 & 0.696825447 & 0.612202896 \\
\hline
\end{tabular}

the value provided may be less meaningful. The model presented can be applied to freehold properties, otherwise other methods belonging to cyclical capitalization group can be applied also to leasehold (d'Amato 2014).

At the moment the determination of the rate of change relies only on the observation of time series and backward holding period determination. For this reason an interesting direction of research can be the determination of property market cycle and the relative $\Delta a_{R R}$ and $\Delta a_{E C}$ using market expectations instead of time series analysis. In this case the rate of change would be based on survey (Wong et al. 2003; Hui, Wong 2004) instead of data analysis. Another interesting direction of research may be also the integration of property market cycle at micro level with other time series at macro level concerning other important indicators such as unemployment or rate of vacancy or the level and the amount of non performing loan. It may be helpful for the determination of the term $n$. Further directions of research may include an extensive comparison on different kinds of income producing properties also belonging to property markets different from the British context. In the last Figure 6 the values of cyclical capitalization were in between the value provided by the Dividend Discount Models applied in the recovery recession and in the expansion contraction phases of the market. Cyclical Capitalization may have a countercyclical behaviour. As a consequence cyclical capitalization application may be a useful contribution for the mortgage lending value determination for income producing properties.

An interesting directions of research include also the application of cyclical capitalization methods dealing with irregular property market cycles. In fact there are cyclical capitalization models addressing the valuation of income producing properties with irregular real estate market cycle.

\section{REFERENCES}

Appraisal Institute, Guide Note n. 12, Analyzing market trends, Chicago, IL. Available at: http://www.appraisalinstitute.org/assets/1/7/guide-note-12.pdf

Appraisal Institute. 2008. The appraisal of real estate, $13^{\text {th }}$ edition. Chicago, IL.

Appraisal Institute. 2012. Uniform standards of professional appraisal practice. The Appraisal Foundation, Chicago, IL.

Borio, C. E. V.; Kennedy, N.; Prowse, S. D. 1994. Exploring aggregate asset price fluctuations across countries, BIS Economic Papers No. 40. Bank for International Settlements.

Case, B.; Goetzmann, W. N.; Watcher, S. M. 1997. The global commercial property market cycles: a comparison across property types, in the AREUEA 6th International Real Estate Conference, 2 June 1997, University of California at Berkeley.

Case, K. E.; Shiller, R. J. 1989. The efficiency of the market for single-family homes, American Economic Review 79(1): 125-137. 
Clayton, J. 1996. Market fundamentals, risk and the Canadian property cycle: implications for property valuation and investment decisions, Journal of Real Estate Research 12(3): 347-367.

d'Amato, M. 2003. Cyclical dividend discount models: linking property market cycles to property valuation, International Journal of Strategic Property Management 7(2): 55-69.

d'Amato, M. 2010. A location value response surface model for mass appraising: an "iterative" location adjustment factor in Bari, Italy, International Journal of Strategic Property Management 14(3): 231-244. http://dx.doi.org/10.3846/ijspm.2010.17

d'Amato, M. 2015. Cyclical capitalization, in Lorenz, D.; Lutzkendorf, T. (Eds.). Beyond the price: valuation in a changing environment. Wiley Publishers, forthcoming.

d'Amato, M.; Kauko, T. 2012a. Sustainability and risk premium estimation in property valuation and assessment of worth, Building Research and Information 40(2): 174-185. http://dx.doi.org/10.1080/096132 18.2012 .655069

d'Amato, M.; Kauko, T. 2012b. Neighbourhood effects, in Smith, S. J.; Elsinga, M.; Eng, O. S.; O’Mahony, L. F.; Watcher, S. (Eds.). International Encyclopedia of Housing and Home. Elsevier Science, 50-54. http:// dx.doi.org/10.1016/B978-0-08-047163-1.00166-1

DeLisle, J.; Grissom, T. 2011. Valuation procedure and cycles: an emphasis on down markets, Journal of Property Investment and Finance 29(4/5): 384-427. http://dx.doi.org/10.1108/14635781111150312

EVA. 2012. European valuation standards, $7^{\text {th }}$ ed. European Group of Valuers' Associations (EVA), Gillis, Belgium.

Gordon, M. 1962. The investment, financing and valuation of the corporation. Homewood: Irwin.

Gordon, M.; Shapiro, E. 1956. Capital equipment analysis: the required rate of profit, Management Science 3(1): 102-110. http://dx.doi.org/10.1287/mnsc.3.1.102

Hekman, J. S. 1985. Rental price adjustment and investment in office markets, Real Estate Economics 13(1): 32-47. http://dx.doi.org/10.1111/1540-6229.00339

Hui, E. C. M.; Wong, J. T. Y. 2004. BRE index for the Hong Kong residential property market, International Journal of Strategic Property Management 8(2): 105-119.

Hui, E. C. M.; Wong, J. T. Y. 2004. BRE index for the Hong Kong residential property market, International Journal of Strategic Property Management 8(2): 105-119. http://dx.doi.org/10.1080/164871 5X.2004.9637511

IVSC. 2011. International valuation standards. International Valuation Standard Council (IVSC), Page Bros, Norwich, London.

IVSC. 2012. Discounted Cash Flow, Technical information paper 1. International Valuation Standard Council (IVSC), Page Bros, Norwich, London.

Malpezzi, S.; Watcher, S. M. 2005. The role of speculation in real estate cycles, Journal of Real Estate Literature 13(2): 143-164.
McCough, T.; Tsolacos, S. 1995. Forecasting commercial rental values using ARIMA models, Journal of Property Valuation and Investment 13: 6-22. http://dx.doi. org/10.1108/14635789510147801

Mueller, G. R.; Laposa, S. P. 1994. Evaluating real estate markets using cycles analyses, in the Annual Meeting of the American Real Estate Society, 15 April 1994, Santa Barbara, CA.

Mueller, G. R.; Laposa, S. P. 1996. Rent distributions under alternative market cycles, in the Annual Meeting of the American Real Estate Society, 28 March 1996, South Lake Tahoe, CA.

Pritchett, C. P. 1984. Forecasting the impact of real estate cycles on investment, Real Estate Review 13(4): 85-89.

Pyhrr, S. A.; Born, W. L.; Robinson, R. R.; Lucas III, S. R. 1996. Real property valuation in a changing economic and market cycle, The Appraisal Journal 64(1): $14-26$.

Pyhrr, S. A.; Roulac, S. E.; Born, W. L. 1999. Real estate cycles and their strategic implications for investors and portfolio managers in the global economy, Journal of Real Estate Research 18(1): 7-68.

Pyhrr, S. A.; Webb, J. R.; Born, W. L. 1990. Analyzing real estate asset performance during periods of market disequilibrium under cyclical economic conditions: a framework for analysis, Research in Real Estate 3: 75-106.

Reed, R.; Wu, H. 2010. Understanding property cycles in a residential market, Property Management 28(1): 33-46.

Reed, R.; Wu, H. 2010. Understanding property cycles in a residential market, Property Management 28(1): 33-46. http://dx.doi.org/10.1108/02637471011017163

Roulac, S. E. 1996. Real estate market cycles, transformation forces and structural change, Journal of Real Estate Portfolio Management 2(1): 1-17.

Scarrett, D. 1990. Property valuation: the 5 methods. London: Spon Press.

Stevenson, S.; McGrath, O. 2003. A comparison of alternative rental forecasting models: empirical tests on the London office market, Journal of Property Research 20(3): 235-260. http://dx.doi. org/10.1080/0959991032000162338

Tse, R. Y. C. 1997. An application of the ARIMA to real estate prices in Hong Kong, Journal of Property Finance 8(2): 152-163. http://dx.doi. org/10.1108/09588689710167843

Voith, R.; Crone, T. 1988. National vacancy rates and the persistence of shocks in the U.S. office markets, Real Estate Economics 16(4): 437-458. http://dx.doi. org/10.1111/1540-6229.00467

Wong, J. T. Y.; Hui, E. C. M.; Seabrooke, W. 2003. The impact of interest rates upon housing prices: an empirical study of Hong Kong's market, Property Management 21(2): 153-170. http://dx.doi. org/10.1108/02637470310478891 